\title{
POLA RELASI PERAN SUAMI-ISTERI DALAM KELUARGA: Studi Kasus Tiga Keluarga Mantan Tenaga Kerja Wanita (TKW) Di Desa Polorejo Kec. Babadan Kabupaten Ponorogo
}

\author{
Oleh: A.Muchaddan Fahham*
}

Dosen STAIN Ponorogo

\begin{abstract}
Abstrak
Tulisan ini bertujuan menjelaskan ada tidaknya pergeseran pola relasi peran suami istri dalam tiga keluarga mantan TKW di desa Polorejo kecamatan Babadan, Kabupaten Ponorogo. Hasil penelitian mernunjukkan bahwa terdapat pergeseran pola relasi peran suami-isteri dalam tiga keluarga mantan TKW. Meski demikian, pergeseran yang terjadi tidak bersifat permanent, dalam arti bahwa pergeseran peran hanya terjadi terutama pada saat sang isteri dari keluarga H-I dan keluarga B-E bekerja di luar negeri. Setelah sang isteri dari kedua keluarga itu kembali ke tengahtengah keluarga, pola relasi peran berjalan sebagaimana yang dulu pernah mereka bangun, yakni sang suami kembali dominan dalam pemenuhan ekonomi keluarga sementara sang isteri juga kembali menekuni pekerjaan domestik dan pengasuhan anak.
\end{abstract}

Kata Kunci: domestik, ekonomi, dan pengasuhan anak

\section{A. Pendahuluan}

Arus migrasi penduduk dari desa ke kota atau dari satu negara ke negara lainnya menunjukkan frekuensi yang kian hari kian meningkat. Meningkatnya frekuensi itu dalam amatan peneliti disebabkan oleh dua faktor, pertama, faktor pendorong (push factors) dan kedua, faktor penarik (pull factors). Faktor pendorong penduduk untuk melakukan migrasi dari satu daerah ke daerah lainnya adalah kondisi ekonomi daerah asal yang masih tergolong miskin dan tidak memungkinkan penduduknya untuk hidup layak, sementara beban hidup makin meningkat. Sedangkan faktor penariknya adalah adanya perbedaan upah yang sangat mencolok antara daerah asal dan daerah tujuan. ${ }^{1}$

Kedua faktor di atas tampaknya juga relevan jika ditarik ke persoalan meningkatnya penduduk usia produktif dari berbagai wilayah di Indonesia untuk

\footnotetext{
* Penelitian ini dibantu oleh Layyin Mahfiana dan Iswahyudi, keduanya juga dosen STAIN Ponorogo.

${ }^{1}$ Abdul Haris, Memburu Ringgit Membagi Kemiskinan: Fakta di Balik Migrasi Orang Sasak ke Malaysia (Yogyakarta: Pustaka Pelajar, 2002), h. 1.
} 
hijrah dan bekerja ke luar negeri seperti Malaysia, Singapura, Brunei Darussalam, Taiwan, Hongkong, Jepang, Saudi Arabia, Abu Dabi dan Negara lainnya. ${ }^{2}$

Salah satu wilayah Indonesia di mana penduduk usia produktifnya banyak pergi ke luar negeri untuk bekarja adalah Ponorogo Jawa Timur. ${ }^{3}$ Sama seperti daerah lainnya di Indonesia, Ponorogo dapat dikatakan merupakan salah satu Kabupaten yang belum mampu menyediakan berbagai macam lapangan kerja bagi penduduk usia produktifnya, dan kalaupun lapangan kerja itu tersedia, sudah dapat diduga bahwa upah yang diterima para pekerja itu tergolong rendah, terutama ketika upah tersebut dibandingkan dengan upah di kota-kota lain, terlebih lagi jika dibandingkan dengan Negara-negara tujuan Tenaga Kerja Indonesia seperti Malaysia, Brunei, Singapura, Taiwan, Hongkong, Jepang, Arab Saudi, dan Abu Dhabi. Di negara-negara tersebut banyak menyediakan lapangan kerja dengan upah yang sangat menjanjikan. Maka tak heran, jika banyak penduduk usia produktif (baca: Tenaga kerja Indonesia) dari wilayah kabupaten Ponorogo yang pergi mengadu nasib ke Negara-negara tersebut. Karena negaranegara tujuan TKI lebih banyak memerlukan tenaga kerja perempuan, maka yang menyambut tawaran tersebut kebanyakan adalah perempuan. ${ }^{4}$

Fenomena isteri bekerja di luar negeri merupakan fenomena yang biasa terjadi di Ponorogo atau di kota-kota lain yang juga merupakan kantong-kantong asal TKI perempuan. Yang menarik dari fenomena ini adalah terjadinya pergeseran peran antara suami dan sang isteri dalam keluarga. Suami yang

\footnotetext{
${ }^{2}$ Menurut penelitian Ridho Rokamah, bahwa terdapat banyak faktor yang mendorong usia produktif untuk menjadi tenaga kerja di luar negeri di antaranya adalah: 1) faktor kemiskinan, karena adanya bujukan untuk mendapatkan penghidupan yang lebih layak. 2) faktor tingkat pendidikan yang rendah, sehingga menyebabkan masyarakat mudah ditipu, 3) faktor kesempatan kerja yang semakin terbatas di Indonesia serta rendahnya upah yang mereka terima, 4) faktor putus asa akan kehidupan dan masa depannya di daerah, 5) adanya informasi pekerja wanita lebih banyak dibutuhkan dari pada laki-laki. Ridho Rokamah, "Mekanisme Pengiriman dan Perlindungan Hukum TKW ke Luar Negeri di Kabupaten Ponorogo" dalam Kodifikasia, No. 1 Tahun 2007.

${ }^{3}$ Berdasarkan hasil penelitian Pusat Studi Wanita (PSW) STAIN Ponorogo Tahun 2006, dinyatakan bahwa salah satu mata pencaharian masyarakat Ponorogo adalah menjadi Tenaga Kerja ke luar negeri, karena itu bukan hal aneh jika di Kabupaten ini setidaknya terdapat 41 (empat puluh satu) perusahaan peneyedia jasa tenaga kerja yang tersebar di beberapa Kecamatan yang ada. Kecamatan kota Ponorogo merupakan tempat di mana PJTKI tumbuh dengan sangat subur, seperti terlihat di Kecamatan ini ada 21 (dua puluh satu) perusahaan PJTKI.

${ }^{4}$ Berdasarkan data yang berhasil digali oleh Tim Penyusun Profil Gender tahun 2005 menunjukkan bahwa jumlah perempuan yang berangkat ke luar negeri lebih banyak jika dibandingkan dengan laki-laki. Perbandingan itu sekitar 79\% perempuan dibanding 21\% laki-laki. Lihat Profil Gender Kabupaten Ponorogo Tahun 2005 (Ponorogo: Pemkab Ponorogo-PSW STAIN Ponorogo, 2006).
} 
biasanya menjadi pencari nafkah keluarga kini perannya berganti sebagai pemelihara keluarga, sementara istri yang lazimnya berperan sebagai pemelihara keluarga kini berganti sebagai pencari nafkah yang utama.

Pertanyaannya kemudian adalah apakah pergeseran peran itu bersifat permanent atau hany bersifat sementara? Dengan ungkapan lain, ketia sang isteri telah kembali dari luar negeri apakah suami tetap mau berperan sebagai pekerja domestik, atau justru yang terjadi sebaliknya di mana suami, tidak lagi mau menjamah pekerjaan-pekerjaan domestic dan menyerahkan semuanya ke tangan isteri. Jika hal terakhir itu terjadi, apa kira-kira yang memicunya dan bagaimana sikap isteri terhadap suami, sebagai orang yang pernah berkorban untuk mencari nafkah keluarga, isteri tentu punya pandangan-pandangan yang khas terhadap keluarga dan suaminya.

Pertanyaan-pertanyaan di atas tidak semua akan dikaji dalam tulisan ini. Secara umum kajian ini menjelaskan ada tidaknya pergeseran pola relasi peran suami istri dalam tiga keluarga mantan TKW di desa Polorejo kecamatan Babadan, kabupaten Ponorogo. Dan jika pergeseran itu ada, mengapa pergeseran itu terjadi atau dengan kata lain, faktor apa yang menjadikan pergeseran itu terjadi. Di samping itu, ia juga menemukan perbedaan pergeseran pola relasi peran dalam tiga keluarga mantan TKW itu.

Perhatian para peneliti terhadap masalah-masalah TKI sesungguhnya cukup besar. Hal itu terlihat dalam hasil-hasil kajian yang telah dilakukan. Tetapi dari sekian hasil penelitian yang ada, dapat dikatakan bahwa belum banyak peneliti yang mencurahkan perhatiannya terhadap persoalan relasi peran suami isteri. Berdasarkan bacaan terhadap hasil penelitian tentang TKW di Kabupaten Ponorogo, peneliti menemukan tiga penelitian yang berkonsentrasi pada persoalan TKW, Pertama, penelitian yang dilakukan oleh Suchamdi tentang Pengaruh Income TKW Terhadap Tingkat Kesejahteraan Keluarga di Desa Polorejo Kecamatan Babadan Kabupaten Ponorogo (Telaah atas Hak dan Kewajiban Suami Isteri Menurut Fiqh Islam) ${ }^{5}$. Kedua, penelitian yang dilakukan oleh Ridho Rokamah tentang mekanisme pengiriman dan perlindungan hukum TKW di

\footnotetext{
5 Suchamdi, Pengaruh Income TKW Terhadap Tingkat Kesejahteraan Keluarga di Desa Polorejo Kecamatan Babadan Kabupaten Ponorogo: Telaah atas Hak dan Kewajiban Suami Isteri Menurut Fiqh Islam (Yogyakarta: Tesis Magister Studi Islam UII, 2003).
} 
Kabupaten Ponorogo. ${ }^{6}$ Ketiga, Ekapi Wahyuni Dj. "Pergeseran Peran dan Fungsi Suami terhadap Pendidikan Anak dalam Keluarga Tenaga Kerja Wanita di Luar Negeri," 7

Dalam Penelitiannya Suchamdi berkesimpulan bahwa: Pertama, dorongan akan peningkatan ekonomi dan kesejahteraan keluarga merupakan motivasi utama TKW untuk bekerja keluar negeri. Kedua, pemasukan ekonomi yang dihasilkan oleh isteri karena bekerja sebagai TKW di luar negeri memiliki pengaruh yang sangat besar bagi kesejahteraan keluarga, meskipun demikian suami tetap bertanggungjawab atas nafkah keluarga. Dengan kata lain, tanggungjawab nafkah keluarga tetap berada pada pundak suami, meskipun isteri memiliki pemasukan ekonomi. Ketiga, Meskipun dalam hukum Islam dikatakan bahwa nafkah keluarga merupakan kewajiban yang harus ditanggung oleh suami tapi tidak berarti isteri dilarang bekerja untuk membantu suami memenuhi kebutuhan ekonomi keluarga. Sebab dalam hukum Islam pada hakikatnya tidak ada larangan bagi isteri untuk bekerja. Isteri bahkan boleh bekerja keluar negeri (TKW), meskipun harus meninggalkan keluarga untuk jangka waktu tertentu dengan syarat mendapat aman dari fitnah, suami dalam keadaan miskin dan mendapat izin suami. Isteri juga boleh bekerja keluar negeri meskipun harus meningalkan kewajibannya sebagai ibu, dengan syarat sebelum keberangkatannya keluar negeri ia telah melimpahkan kewajiban tersebut kepada orang yang ia percaya seperti suami dan nenek.

Berbeda dengan penelitian di atas, Ridho Rokamah, menelaah persoalan TKW dari sisi mekanisme pengiriman dan perlindungan hukumnya, ada empat persoalan yang jadi focus penelitian ini, (1) tentang latar belakang yang menyebabkan masyarakat Ponorogo, khususnya perempuan menjadi TKW ke luar negeri, 2) tentang prosedur/mekanisme pengiriman TKW ke luar negeri di Kabupaten Ponorogo, 3) tentang bentuk-bentuk perlindungan hukum yang diperoleh TKW ke luar negeri di Kabupaten Ponorogo, 4) tentang masalahmasalah yang muncul dalam mekanisme pengiriman TKW di Kabupaten

\footnotetext{
${ }^{6}$ Ridho Rokamah, Mekanisme Pengiriman dan Perlindungan Hukum TKW ke Luar Negeri di Kabupaten Ponorogo (Ponorogo:P3M STAIN Ponorogo, 2007).

${ }^{7}$ Ekapi Wahyuni Dj. "Pergeseran Peran dan Fungsi Suami terhadap Pendidikan Anak dalam Keluarga Tenaga Kerja Wanita di Luar Negeri,” dalam Fenomena Vol. 4 No. 2, Juli 2007. h. 90102 .
} 
Ponorogo dan implikasinya terhadap perlindungan hukum TKW di Kabupaten Ponorogo.

Berdasarkan analisis yang dilakukan Ridho Rokamah berkesimpulan bahwa terdapat banyak pelanggaran dalam mekanisme pengiriman TKW, mulai dari proses awal sampai akhir, perlindungan hukum yang diberikan kepada TKW juga masih lemah sehingga berdampak pada rentannya mereka terhadap penipuan dan kekerasan. Penyebab terjadinya pelanggaran atau lemahnya perlindungan hukum di Ponorogo ini sangat kompleks yaitu, faktor sosial, budaya, kesadaran masyarakat rendah, aparat penegak hukum lemah, pemahaman agama masih bias, dan fasilitas dana masih sangat minim untuk mendukung terealisasinya Undangundang No.39 tahun 2004.

Sementara Ekapi Wahyuni Dj., dalam penelitian tentang pergeseran peran dan fungsi suami terhadap pendidikan anak dalam keluarga enaga kerja wanita di luar negeri menyimpulkan bahwa terdapat dua faktor yang mendorong seorang ibu rumah tangga atau isteri untuk menjadi TKW di luar negeri, yaitu, keinginan dari dari dalam dirinya sendiri dan dorongan dari luar diri. Selanjutnya disebutkan juga bahwa peran dan fungsi suami dalam pemenuhan kebutuhan keluarga, sehingga perang ganda suami (ayah) menjadi tidak terlalu berat dan dapat menekan konflik peran sebagai kepala keluarga; sementara dampak kepergian ibu rumah tangga (isteri) menjadi TKW di luar negeri terhadap pendidikan anak sangat besar pengaruhnya. Dalam hal ini keterlibatan suami secara aktif sangat menentukan keberhasilan pendidikan anak. ${ }^{8}$

\section{B. Metode Penelitian}

Penelitian ini merupakan penelitian lapangan yang menggunakan pendekatan fenomenologi. Adapun langkah-langkah penelitiannya adalah sebagai sebagai berikut: Merumuskan permasalahan sesuai dengan ruang lingkup penelitian, kemudian menyusun desain operasional penelitian, termasuk pedoman wawancara; Melakukan penelaahan terhadap literatur yang relevan dengan masalah penelitian, Menghubungi informan awal untuk mendapat masukan atau informasi awal mengenai obyek yang hendak diteliti; Setelah menentukan

\footnotetext{
${ }^{8}$ Ibid. h. $90-102$.
} 
informan yang diteliti, dilakukan observasi lapangan, wawancara mendalam terhadap informan-informan; Mengumpulkan dan mengolah data yang diperoleh dari lapangan; Menganalisis dan memberikan interpretasi data yang telah diolah; Membuat draft laporan sambil mengecek ulang data yang masih belum memadai untuk dilengkapi; Mendiskusikan hasil penelitian [sementara] dengan pihak-pihak terkait; sambil menyiapkan laporan akhir; Pelaporan dan seminar hasil dengan mengundang berbagai pihak terkait yang berkompeten.

Instrumen pengumpulan data yang digunakan dalam penelitian ini adalah: Pertama, observasi Langsung. Untuk memperoleh akses langsung terhadap obyek yang diteliti, tim akan melakukan observasi langsung terhadap masyarakat yang menjadi obyek penelitian. Observasi dimaksudkan untuk mendapat informasi awal mengenai persaoalan yang ada, sehingga dimungkinkan adanya kontak dan kerjasama dalam wawancara yang lebih lanjut. Kedua, Wawancara Mendalam (indepth interview) teknik ini digunakan untuk mewawancarai sebagian informan. Wawancara ini akan dilakukan secara dialogis, terarah dan intensif. Meskipun teknik wawancara digulirkan seperti "bola salju," namun substansi permasalahan tetap mengacu pada pedoman yang telah dirancang. Wawancara ini dilakukan terhadap tiga informan keluarga matan TKW di Desa Polorejo Kecamatan Babadan Kabupaten Ponorogo.

\section{Hasil Penelitian}

\section{Profil Keluarga H dan I}

Keluarga $\mathrm{H}$ dan isterinya, I, adalah orang Ponorogo asli, mereka tinggal di desa yang masyarakatnya cukup heterogen terutama jika dilihat dari tingkat pendidikan dan ekonominya. Keluarga ini mempunyai dua orang anak perempuan, satu berumur sepuluh (kelas 5 Madrasah Ibtidaiyah) dan satu lagi berumur empat tahun (belum sekolah). I Istri $\mathrm{H}$ adalah lulusan Madrasah Aliyah sementara $\mathrm{H}$ lulusan Pondok Pesantren Tahfidh al-Qur'an, H bahkan mendapat gelar al-Hafidh. H lulusan Sekolah Menengah Pertama (SMP), masa remajanya dihabiskan untuk menimba ilmu al Qur'an di sebuah pondok pesantren hingga di mendapat gelar al Hafidz. ${ }^{9}$ Setelah menikah H dan I, secara ekonomi tergolong keluarga pas-pasan:

\footnotetext{
${ }^{9}$ Hasil wawancara pada tanggal 5 Nopember 2007
} 
$\mathrm{H}$ belum punya pekerjaan tetap, hasil sawahnya juga belum cukup untuk memenuhi kebutuhan mereka sehari-hari. Kondisi keluarga yang pas-pasan itulah kemudian yang mendorong I bekerja di luar negeri sebagai TKW: I pernah bekerja rumah sakit di Jeddah selama enam tahun. Dari hasil kerjanya itu, keluarga ini membeli tanah sawah seluas 2000 meter persegi. Di samping membeli sawah, hasil kerja tersebut juga dapat digunakan untuk membangun rumah di atas tanah pemberian orang tua I (isteri $\mathrm{H}$ ) seluas 300 meter. Akan tetapi rumah yang mereka bangun itu belum layak ditempati: belum diberi kramik dan dicat. $^{10}$

Kondisi ekonomi keluarga yang belum mapan secara ekonomi itu mendorong I untuk untuk berangkat lagi ke Abu Dhabi untuk menjadi sebagai pembantu rumah tangga melalui bantuan temannya yang sudah lebih dahulu disana dengan menggunakan jalur Calling Visa ( Calon majikan sudah menyediakan tiket pesawat dan Visa kerja untuk calon pembantu mereka). I bekerja selama dua tahun, setelah pulang, uang hasil menjadi TKW digunakan untuk memperbaiki rumah, kemudian I berangkat lagi menjadi TKW ke Singapura melalui jalur Calling Visa dari majikan saudaranya, akan tetapi I hanya bertahan satu tahun di sana, kemudian berangkat lagi ke Saudi Arabia melalui jalur yang sama, dan bertahan di Saudi Arabia selama dua tahun, setelah itu I tidak berangkat lagi karena suami sudah tidak mengijinkan, sekarang dia menjadi Ibu rumah tangga dan merawat dua anaknya. ${ }^{11}$ Kini $\mathrm{H}$ dan I tergolong hidup berkecukupan, H sekarang berprofesi sebagai Tukang Pijet Urat, setiap hari pasien datang sekitar 10-15 orang, belum lagi apabila hari libur jumlah pasien bisa bertambah banyak. Mereka tinggal di rumahnya sendiri berukuran 300 meter persegi, yang terdiri dari satu kamar tamu, satu kamar pasien, 3 kamar tidur, satu ruang makan, ruang dua kamar mandi dan dapur. Mereka memiliki halaman yang luas, ditanami berbagai macam bunga yang subur dan terawat dengan rapi.

\section{a. Pola Relasi Peran Domestik}

$\mathrm{H}$ dan I tidak mempunyai pembantu, oleh karena itu hamper semua pekerjaan domestik hampir dikerjakan oleh I, anaknya yang berumur 10 tahun

\footnotetext{
${ }^{10}$ Hasil wawancara pada tanggal 2 Nopember 2007

${ }^{11}$ Hasil wawancara tanggal 10 Nopember 2007
} 
sebenarnya sudah dapat membantunya meskipun hanya menyapu halaman setiap pagi sebelum sekolah. ${ }^{12}$ Lebih jelasnya tentang pola relasi peran domestik keluarga $\mathrm{H}$ dan I dapat dilihat pada tabel berikut:

\begin{tabular}{|c|c|c|c|}
\hline Jenis Pekerjaan $^{13}$ & $\mathbf{H}$ & $\mathbf{I}$ & $\mathbf{S}$ \\
\hline Mencuci pakaian & & $\sqrt{ }$ & \\
\hline Menjemur pakaian & & $\sqrt{ }$ & \\
\hline Menyeterika & & $\sqrt{ }$ & \\
\hline Membersihkan Kamar Mandi & & $\sqrt{ }$ & \\
\hline Membersihkan wc & & $\sqrt{ }$ & \\
\hline Mencuci alat Masak & & $\sqrt{ }$ & \\
\hline Mencuci alat makan & $*$ & $\sqrt{ }$ & \\
\hline Belanja & & $\sqrt{ }$ & \\
\hline Memasak & & $\sqrt{ }$ & \\
\hline Menyapu halaman & & & $\sqrt{ }$ \\
\hline Mengepel & & $\sqrt{ }$ & \\
\hline Bersih-Bersih Taman & $*$ & $\sqrt{ }$ & \\
\hline Menyirami tanaman/kebun & & $\sqrt{ }$ & \\
\hline Bersih-bersih rumah & & $\sqrt{ }$ & \\
\hline Bersih-bersih, kamar, tempat tidur & & $\sqrt{ }$ & $\sqrt{ }$ \\
\hline Memberi makan hewan peliharaan & - & - & - \\
\hline Memperbaiki lampu & $\sqrt{ }$ & & \\
\hline Mencuci Karpet & & $\sqrt{ }$ & \\
\hline Mencuci sprai & & $\sqrt{ }$ & \\
\hline Mencuci motor & $\sqrt{ }$ & & \\
\hline
\end{tabular}

Menurut $\mathrm{H}$ pekerjaan domestik merupakan pekerjaan isteri sehari-hari, ${ }^{14}$ oleh karena itu, $\mathrm{H}$ hanya membantu dalam hal-hal tertentu saja. Meskipun selama I menjadi TKW di luar negeri kerja-kerja domestik dikerjakan oleh $\mathrm{H}$. tapi setelah I pulang kerja-kerja tersebut dikerjakan kembali oleh I. mengapa demikia? Menurut $\mathrm{H}$, begitulah yang diatur dalam ajaran agama: suami bekerja di ruang publik sementara isterei bekerja di ruang domestik.

\section{b. Pola Relasi Peran Ekonomi}

\footnotetext{
${ }^{12}$ Ibid.

${ }^{13}$ Simbol Pekerjaan yang sering dilakukan oleh Informan ditandai dengan simbol " $\sqrt{ }$, sedangkan "*" merupakan simbol pekerjaan yang jarang dilakukan oleh Informan.

${ }^{14}$ Hasil wawancara tanggal 12 Nopember 2007
} 
Latar belakang ekonomi keluarga $\mathrm{H}$ adalah pas-pasan, $\mathrm{H}$ adalah anak nomor tiga dari tujuh bersaudara. Sedangkan I adalah anak nomor tiga dari delapan bersaudara dan tergolong keluarga yang berkecukupan. Tanah untuk membuat rumah merupakan pemberian dari keluarga I. Setiap hari $\mathrm{H}$ bekerja di dalam dan di luar rumah, sebagai tukang pijet urat dan pagi harinya setelah shalat subuh, $\mathrm{H}$ mengajar mengaji di lingkungan sekitarnya.

Seperti telah disnggung sebelumnya bahwa $\mathrm{H}$ tergolong Tukang Pijat yang cukup laris, setiap hari $\mathrm{H}$ bisa melayani pasiennya 10-15 kali, apalagi pada musim libur bisa jauh lebih banyak. Setiap pasien, memberikan upah beragam, ada yang 15 ribu, 20 ribu bahkan ada juga yang 50 ribu. Semua uang hasil kerjanya dipegang oleh $\mathrm{H}$, ia hanya memberikan jatah bulanan kepada I sebesar Rp. 500.000,-, Dan jika jumlah itu belum mencukupi I akan meminta lagi kepada $\mathrm{H}$. Biaya pendidikan anak seperti SPP sekolah anak menjadi tanggungjawab $\mathrm{H}^{15}$ Pengeluaran rutin keluarga seperti kebutuhan makan sehari-hari dikelola oleh I sang isteri. Hanya saja apabila masakan kurang berkenan di hati $\mathrm{H}$ atau apabila $\mathrm{I}$ tidak memasak, $\mathrm{H}$ sering belanja lauk pauk sendiri di warung langganannya. Untuk pengeluaran lainnya selalu dimusyawarahkan bersama-sama. ${ }^{16}$

\section{c. Pola Relasi Peran Pengasuhan Anak}

Dalam keluarga $\mathrm{H}$, anak hampir sepenuhnya diasuh oleh istri. $\mathrm{H}$ hanya sekali-kali saja menggendong, memandikan dan menyuapinya, $\mathrm{H}$ beranggapan bahwa tanggung jawab marawat dan mengasuh anak ada pada ibu. ${ }^{17}$ Akibatnya anak lebih dekat dengan ibu dan bahkan cenderung takut sama bapaknya. Padahal selama ditinggal I menjadi TKW semua pekerjaan pengasuhan anak berada di tangan H. setelah I pulang, semua pekerjaan tersebut diserahkan kepada I dengan alasan bukan kewajiban suami untuk merawat dan mengasuh anak. Karena Anak yang kedua masih berumur 4 tahun, $\mathrm{S}$ (anak pertamanya) seringkali membatu ibunya untuk menemani sang adik bermain, itu dilakukan setelah $\mathrm{S}$ pulang sekolah atau ketika hari libur tiba.

\footnotetext{
${ }^{15}$ Hasil wawancara tanggal 15 Nopember 2007

${ }^{16}$ Hasil wawancara tanggal 15 Nopember 2007

17 Ibid.
} 


\begin{tabular}{|l|c|c|c|}
\hline Pelaku & & & \\
Menis Pekerjaan & H & I & S \\
\hline Memadurkan & & $\sqrt{ }$ & \\
\hline Menggantikan & $*$ & $\sqrt{ }$ & \\
\hline Menyuapi & $*$ & $\sqrt{ }$ & \\
\hline Menemani bermain & $*$ & $\sqrt{ }$ & $\sqrt{ }$ \\
\hline Menemani belajar & & $\sqrt{ }$ & \\
\hline
\end{tabular}

Di samping tidak lagi punya cukup waktu untuk menemani sang anak belajar, bagi I sang isteri, pelajaran kelas lima Madrasah Ibtidaiyah merupakan pelajaran yang cukup sulit, maka $\mathrm{H}$ mendatangkan guru privat untuk membantu anaknya belajar. Guru tersebut dating setiap malam keculi pada hari libur.

\section{Keluarga $S$ dan $R$}

$\mathrm{S}$ dan keluarga tinggal di pemukiman masyarakat yang agamis, dekat pondok pesantren. S mempunyai dua orang anak. Anak pertama perempuan berumur 12 tahun (kelas 2 Tsanawiyah), anak kedua laki-laki berumur 4 tahun. $\mathrm{S}$ bekerja serabutan, pada musim tanam padi dia ikut menjadi buruh tani: membajak sawah, sementara pada musim panen dia ikut menjadi buruh memanen. Begitu juga dengan $\mathrm{R}$ isteri $\mathrm{S}$ : menjadi buruh tani ketika musim tanam padi (tandur) tiba, mencabuti hama rumput (matun) dan memetik lombok (ketika musim panen lombok tiba). ${ }^{18}$

$\mathrm{S}$ dan $\mathrm{R}$ menikah 14 tahun yang lalu, setelah menikah, mereka tinggal bersama orang tua S. S anak ke dua dari 6 bersaudara. Dua tahun setelah pernikahan mereka dikaruniai momongan, setelah anak mereka berumur 1.5 tahun R bekerja sebagai TKW di Arab Saudi. Setelah dua tahun, R Pulang ke Ponorogo dan membangun rumah dari hasil kerjanya tersebut di atas tanah pemberian orang tua $\mathrm{S}$ seluas 180 meter persegi. Begitu rumah sudah didirikan $\mathrm{R}$ berangkat lagi ke Arab Saudi, dua tahun pulang lagi dan memperbaiki rumah hingga sekarang rumah yang mereka tempati sudah layak, berpagar tembok, berkeramik, memiliki 2 kamar tidur, satu ruang tamu, satu ruang keluarga, satu ruang makan dan dapur.

\footnotetext{
${ }^{18}$ Hasil wawancara tanggal 3 September 2007
} 
Mulai awal menikah hingga sekarang $\mathrm{R}$ sudah 4 kali menjadi TKW $(4 \times 2$ tahun $=$ 8 tahun), terakhir dia berangkat di tahun 2005 saat anak kedua berumur satu tahun. Hasil yang diperoleh $\mathrm{R}$ dari luar negeri selain untuk membuat dan memperbaiki rumah, juga digunakan untuk membeli tanah sawah seluas 1000 meter persegi di samping untuk membeli sepeda motor baru buatan China. ${ }^{19}$

Latar belakang pendidikan mereka sama: Setelah lulus Tsanawiyyah, S menimba ilmu di salah satu Pondok Pesantren di Nganjuk selama 5 tahun. ${ }^{20}$ Dan R sebenarnya bukan orang asli Ponorogo, dia berasal dari Dlopo Madiun, akan tetapi sejak kecil dia diasuh neneknya di Ponorogo. Setelah selesai Tsanawiyah R ikut kedua orang tuanya di Dlopo Madiun, umur 18 tahun di bekerja ke Arab Saudi selama dua tahun, hasil bekerjanya digunakan untuk mencukupi kebutuhan keluarganya sehari-hari diantaranya memperbaiki rumah dan membantu sekolah ke 4 adiknya. $^{21}$

$\mathrm{S}$ dan $\mathrm{R}$ sekarang hidup berkecukupan meskipun mereka harus menjadi buruh tani kesana kemari. Mereka memiliki rumah bagus yang sekelilimhnya diberi pagar tembok. Meskipun demikian, dilihat dari kacamata kesehatan, rumah tersebut sejatinya kurang higienis karena di samping rumah yang mereka tempati itu terdapat kandang kambing, mereka memiliki 2 kambing sebagai binatang peliharaan. Menurut R, sekarang dia belum pingin menjadi TKW lagi, karena dia ingin melihat perkembangan anak keduanya, menemani sekolah tahun ajaran baru ini dan menemaninya belajar. ${ }^{22}$

\section{a. Pola Relasi Peran Domestik}

Dalam keluarga S dan R kerja domestik selalu mereka lakukan bersamasama, bahkan S cenderung dominan dalam melakukan pekerjaan tersebut. Putri pertamanya $U$ hanya membantu dalam hal-hal tertentu saja. Lebih jelasnya kerjakerja domestic dalam keluarga ini dapat dilihat dalam tabel sebagai berikut:

\footnotetext{
${ }^{19}$ Hasil wawancara tanggal 4 September 2007

${ }^{20}$ Hasil wawancara tanggal 3 September 2007

${ }^{21}$ Hasil wawancara dengan Rohmi tanggal 4 September 2007

22 Ibid.
} 


\begin{tabular}{|l|c|c|c|}
\hline Pelaku & \multicolumn{2}{|c|}{ S } & U \\
\hline Jenis Pekerjaan & R & $\sqrt{ }$ & \\
\hline Mencuci pakaian & & $\sqrt{ }$ & \\
\hline Menjemur pakaian & & $\sqrt{ }$ & \\
\hline Menyeterika & & $\sqrt{ }$ & \\
\hline Membersihkan Kamar Mandi & & $\sqrt{ }$ & \\
\hline Membersihkan wc & $\sqrt{ }$ & $\sqrt{ }$ \\
\hline Mencuci alat Masak & $\sqrt{ }$ & $\sqrt{ }$ & \\
\hline Mencuci alat makan & $\sqrt{ }$ & $\sqrt{ }$ & \\
\hline Belanja & $\sqrt{ }$ & $\sqrt{ }$ & \\
\hline Memasak & $*$ & $\sqrt{ }$ & \\
\hline Menyapu halaman & $\sqrt{ }$ & $\sqrt{ }$ & \\
\hline Mengepel & $\sqrt{ }$ & $\sqrt{ }$ & \\
\hline Bersih-Bersih Taman & $\sqrt{ }$ & $\sqrt{ }$ & $\sqrt{ }$ \\
\hline Menyirami tanaman/kebun & $*$ & $\sqrt{ }$ & \\
\hline Bersih-bersih rumah & & $\sqrt{ }$ & \\
\hline Bersih-bersih, kamar, tempat tidur & & $\sqrt{ }$ & \\
\hline Memberi makan hewan peliharaan & $*$ & $\sqrt{ }$ & \\
\hline Memperbaiki lampu & & $\sqrt{ }$ & \\
\hline Mencuci Karpet & & & \\
\hline Mencuci sprai & & & \\
\hline Mencuci motor & & & \\
\hline
\end{tabular}

Porsi besar dalam kerja domestic yang dilakukan oleh $\mathrm{S}$ karapkali mendapat respon negative dari lingkungan sekitarnya. Padahal dalam perspektif gender, relasi peran yang seimbang dalam keluarga ini tentu saja sangat diharapkan.

\section{b. Pola Relasi Peran Ekonomi}

Latar belakang ekonomi keluarga $\mathrm{S}$ tergolong keluarga yang pas-pasan. Keluarga $\mathrm{S}$ hanya memberikan tanah untuk membangun rumah. Pada akhirnya mereka harus berjuang sendiri untuk memenuhi kebutuhan hidup keluarganya. Mereka sama-sama sadar akan kekurangan tersebut, karena hasil mengelola tanahnya yang 1000 meter persegi itu tidak cukup untuk memenuhi kebutuhan sehari-hari. Mereka melakukan pekerjaan apa saja yang mereka mampu, yakni menjadi buruh tani: mereka biasa menggarap sawah dengan system bagi hasil 
terutama ketika ada orang yang menyerahkan tanahnya untuk mereka garap, membajak sawah, menanam padi atau palawija, dan mencabuti rumput. ${ }^{23}$

Dalam hal pembagian keuangan dalam rumah tangga, mereka selalu mengkomunikasikan bersama, uang hasil kerja mereka disatukan untuk mencukupi kebutuhan hidup mereka sehari-hari. Untuk masalah belanja kebutuhan domestik, $\mathrm{R}$ yang berperan, akan tetapi untuk kebutuhan lainnya mereka selalu mengkomunikasikan bersama.

\section{c. Pola Relasi Peran Pengasuhan Anak}

Oleh karena R lama bekerja keluar negeri sebagai TKW, maka anak-anak mereka lebih dekat pada bapaknya. Kondisi ini berakibat pada pengasuhan anak, yakni S dominan dalam mengasuh mereka.Hal ini dapat dilihat dari tabel di bawah ini:

\begin{tabular}{|l|c|c|c|}
\hline Jenis Pekerjaan & R & S & U \\
\hline Menidurkan & & & \\
\hline Memandikan & $*$ & $\sqrt{ }$ & \\
\hline Menggantikan Popok & $\sqrt{ }$ & $\sqrt{ }$ & $*$ \\
\hline Menyuapi & $\sqrt{ }$ & $\sqrt{ }$ & $\sqrt{ }$ \\
\hline Menemani bermain & $\sqrt{ }$ & $*$ & $\sqrt{ }$ \\
\hline Menemani belajar & $*$ & $\sqrt{ }$ & \\
\hline
\end{tabular}

Bagi R kedekatan anak kepada bapaknya bukanlah merupakan masalah, dia menganggap itu sebagai suatu hal yang wajar saja, bahkan kedekatan S dengan anak-anaknya lebih menenangkan $\mathrm{R}$, sebab dia dapat bekerja di sawah dengan tenang tanpa memikirkan anak yang rewel di rumah. ${ }^{24}$

\section{Keluarga B dan $E$}

B dan E hidup di lingkungan masyarakat yang agamis di dekat rumah mereka terdapat pondok salafiah tahfidh al-Qur'an, mereka dikaruniai satu orang anak perempuan berumur 10 tahun (kelas 5 Madrasah Ibtidaiyah), mereka tinggal

\footnotetext{
${ }^{23}$ Hasil wawancara tanggal 10 September 2007

${ }^{24}$ Hasil wawancara tanggal 4 September 2007
} 
berdampingan dengan rumah saudara laki-laki E, tanah yang digunakan untuk membuat rumah adalah tanah warisan dari keluarga E seluas 95 meter persegi.

Kini, keseharian B adalah bekerja sebagai Penjual Pulsa dan Penjual Jamu. Usaha itu dibangun berdasarkan dana yang didapat E dari bekerja di luar negeri sebagai TKW. Meskipun tempat usaha itu bukan milik mereka tapi milik orang lain yang mereka sewa untuk mengembangkan usaha. ${ }^{25}$

Cerita keluarga ini cukup unik: keduanya pernah bekerja ke luar negeri. Sebelum menikah B bekerja pada bengkel motor di dekat rumahnya, setelah dua tahun menikah, E pergi bekerja ke luar negeri selama 2 tahun sebagai TKW. Hasil kerja dua tahun itu mereka gunakan untuk membangun rumah, tapi karena dana yang tersedia tidak mencukupi maka rumah yang mereka bangun belum sempurna meskipun sudah bias ditempati. Setelah setahun berlalu, gilaran B yang merantau ke Malaysia selama dua tahun. Setelah itu B kembali dan lima bulan setelahnya E berangkat lagi ke Arab Saudi. Hasil kerja di luar negeri mereka gunakan untuk menyempurnakan rumah seperti mengecat dan memasang keramik. Kini rumah mereka sudah bagus, bercat hijau, berkeramik hijau terdiri dari satu kamar tamu, 3 kamar tidur, satu ruang makan dan dapur.

Di samping untuk membangun rumah, hasil kerja mereka sebagai TKW dan TKI, mereka mereka gunakan untuk membeli sepeda motor, membiayai sekolah anak, dan seperti telah disebutkan untuk menyewa toko sebagai tempat usaha: Counter Handphone Toko Jamu.

E merupakan anak bungsu dari 6 bersaudara, bapak ibunya sudah meninggal sejak 12 tahun yang lalu. B merupakan anak pertama dari tiga bersaudara, oleh karena itu dia cenderung mandiri dalam mencukupi kebutuhan istri dan anaknya, karena harta orang tuanya digunakan untuk mencukupi kebutuhan adik-adiknya yang masih sekolah.

\section{a. Pola Relasi Peran Domestik}

Karena mereka sekeluarga hidup mandiri: apabila E pergi menjadi TKW, semua pekerjaan domestic dikerjakan oleh $\mathrm{B}$, anaknya (Kiki) hanya membantu membersihkan lantai saja itupun kalau sang anak mau, sebaliknya jika B yang

\footnotetext{
${ }^{25}$ Hasil Wawancara dengan B tanggal 4 Agustus 2007
} 
menjadi TKI, maka E yang mengerjakan semua pekerjaan domestik. Dan jika mereka telah kembali dan berkumpul seperti sekarang ini, maka E-lah yang lebih dominan dalam melakukan pekerjaan domestic. Seperti terlihat dalam table dibawah ini:

\begin{tabular}{|l|c|c|c|}
\hline \multicolumn{1}{r|}{ Pelaku } & & & \\
Jenis Pekerjaan & B & E & \\
\hline Mencuci pakaian & & $\sqrt{ }$ & \\
\hline Menjemur pakaian & & $\sqrt{ }$ & \\
\hline Menyeterika & & & \\
\hline Membersihkan Kamar Mandi & $*$ & $\sqrt{ }$ & \\
\hline Membersihkan wc & $*$ & $\sqrt{ }$ & \\
\hline Mencuci alat Masak & & & \\
\hline Mencuci alat makan & $*$ & $\sqrt{ }$ & \\
\hline Belanja & $*$ & $\sqrt{ }$ & \\
\hline Memasak & $*$ & $\sqrt{ }$ & \\
\hline Menyapu halaman & $*$ & $\sqrt{ }$ & \\
\hline Mengepel & $*$ & $\sqrt{ }$ & \\
\hline Bersih-Bersih Taman & $*$ & $\sqrt{ }$ & \\
\hline Menyirami tanaman/kebun & $*$ & $\sqrt{ }$ & $\sqrt{ }$ \\
\hline Bersih-bersih rumah & & & \\
\hline $\begin{array}{l}\text { Bersih-bersih, kamar, tempat } \\
\text { tidur }\end{array}$ & & & \\
\hline $\begin{array}{l}\text { Memberi makan } \\
\text { peliharaan }\end{array}$ & $\sqrt{ }$ & & \\
\hline Memperbaiki lampu & $\sqrt{ }$ & \\
\hline Mencuci Karpet & & & \\
\hline Mencuci sprai & & & \\
\hline Mencuci motor & & & \\
\hline
\end{tabular}

Menurut B, jika istri dirumah, maka semua pekerjaan domestik adalah pekerjaan istri, suami sifatnya hanya membantu tugas istri jika suami memiliki banyak waktu. $^{26}$

\section{b. Pola Relasi Ekonomi}

B bekerja sebagai wiraswasta dan istrinya sebagai ibu rumah tangga. Sang isteri akan membantu suami di took jika pekerjaan rumah telah selesai ia kerjakan.

\footnotetext{
${ }^{26}$ Ibid
} 
Masalah keuangan di serahkan kepada istri: bertanggungjawab penuh atas keperluan belanja keluarga sehari-hari. Selebihnya jika mereka hendak menggunakan uang untuk keperluan yang sekunder, misalnya televise, sepeda motor dan lain sebagainya mereka selalu mendiskusinkannya.

\section{c. Pola Relasi Peran Pengasuhan Anak}

B mempunyai satu orang anak, dalam pengasuhan anak mereka mengasuhnya bersama-sama, mana yang sempat dan punya waktu luang itu yang mengerjakan, selengkapnya dapat dilihat dalam tabel di bawah ini:

Tabel Pengasuhan Anak

\begin{tabular}{|l|c|c|c|}
\hline \multicolumn{1}{|c|}{ Pelaku } & \multicolumn{2}{|c|}{ E } & Paman \\
\hline Menis Pekerjaan & B & \multicolumn{2}{|c|}{ E } \\
\hline Memandikan & $\sqrt{ }$ & $\sqrt{ }$ & \\
\hline Menyuapi & $\sqrt{ }$ & $\sqrt{ }$ & \\
\hline Mengantarsekolah & $\sqrt{ }$ & $\sqrt{ }$ & $\sqrt{ }$ \\
\hline Menjemputsekolah & $\sqrt{ }$ & $\sqrt{ }$ & $\sqrt{ }$ \\
\hline Menemani belajar & $\sqrt{ }$ & $\sqrt{ }$ & \\
\hline
\end{tabular}

Pengasuhan anak dalam keluarga B selalu dikomunikasikan secara bersama-sama. Menurut E, hal ini dilakukan karena Kiki (anaknya) masih anak satu-satunya jadi pengasuhan harus bersama, akan tetapi kalau nanti punya adik, baru dibagi-bagi pembagian tugas dalam pengasuhan anak ${ }^{27}$.

\section{Memahami Pola Relasi Peran Suami Istri Dalam Keluarga Mantan TKW Di Desa Polorejo Babadan Kabupaten Ponorogo}

Dalam bagian ini peneliti akan menjelaskan pola relasi peran suami-isteri keluarga mantan TKW di desa Polorejo Kecamatan Babadan Kabupaten Ponorogo. Penjelasan tersebut bertolak dari satu pertanyaan mendasar, apakah telah terjadi pergeseran peran suami-isteri dalam keluarga mantan TKW setelah sang isteri pulang dari luar negeri. Sebab sebelumnya hampir semua pekerjaan domestik menjadi tanggungjawab suami, sementara sang isteri bertanggungjawab sebagai pencari nafkah di luar negeri. Tanggungjawab suami akan pekerjaan

\footnotetext{
${ }^{27}$ Wawancara dengan E tanggal 10 Agustus 2007
} 
domestik itu sejatinya telah berjalan kurang lebih antara 2 sampai dengan 6 tahun, berdasarkan waktu tanggungjawab itu sesungguhnya cukup lama, namun apakah setelah isteri pulang dari luar negeri tanggungjawab itu kembali ke tangan isteri atau justru terjadi relasi yang adil, di mana suami tetap ikut berpartisipasi dalam kerja-kerja domestik sang isteri, kemudian siapa yang bertanggungjawab atas pencarian nafkah keluarga, apakah tetap isteri atau suami, jika isteri adakah dalam kasus tersebut terjadi semacam beban kerja yang ganda, di satu sisi isteri tetap sebagai pencari nafkah namun di sisi lain lain ia juga dibebani oleh kerja-kerja domestic dalam keluarga.

Ada tiga relasi peran yang akan dilihat dalam konteks ini, pertama, peran dalam kerja domestic, kedua, peran dalam pencarian nafkah keluarga, dan ketiga peran dalam pendidikan dan perawatan anak.

\section{Pola Relasi Peran Domestik}

Berdasarkan data yang telah dideskripsikan pada bagian sebelumnya tentang pola relasi peran suami-isteri dalam kerja domestik terlihat bahwa dalam keluarga $\mathrm{H}$ dan I, terjadi pergeseran peran, sebab pasca kepulangan sang istri dari luar negeri, maka seketika itu pula I sang isteri kembali melakukan kerjakerja domestiknya sebagai isteri yang mengerjakan hampir semua pekerjaan rumah: mulai mencuci pakian, menjemur, menyetrika, membersihkan kamar mandi, membersihkan wc, mencuci alat masak, memncuci alat makan, belanja, memasak, menyapu halaman, mengepel, bersih-bersi taman, menyirami tanaman, bersihberisih kamar, bersih-bersih rumah, sampai mencuci karpet. Sementara H, sang suami kembali ke tanggungjawab awalnya sebagai pencari nafkah keluarga dengan menjadi tukang pijat urat.

Di sisi lain, keluarga kedua, yaitu keluarga $\mathrm{S}$ dan $\mathrm{R}$ justru melakukan pekerjaan domestik rumah tangga mereka secara bersama-sama, bahkan pekerjaan itu cenderung dilakukan oleh $\mathrm{S}$, mulai dari menyetrika, mencuci alat masak, belanja, memasak, menyapu halaman, mengepel, menyiram tanaman, bersihbersih rumah, bersih-bersih kamar mandi, kamar, dan tempat tidur. Namun demikian sisi menariknya, kecenderungan S untuk ikut terlibat secara aktif dalam 
melakukan pekerjaan domestic mendapat sorotan dari tetangga sekitar maupun kerabat-kerabat dan keluarga besarnya.

Sementara pada keluarga B dan E, seperti juga yang terjadi dalam keluarga $\mathrm{H}$ dan I, semua pekerjaan domestik dikerjakan oleh E, sang isteri, mulai dari mencuci pakaian, mnejemur pakaian, menyetrika, membersihkan kamar mandi, memberihkan wc, mencuci alat masak, mencuci alat makan, belanja, memasak, menyapu halaman, mengepel, bersih-bersih taman, menyirami tanaman/kebun, bersih-bersih rumah, bersih-bersih kamar, dan tempat tidur.

\section{Pola Relasi Peran Ekonomi}

Dalam hal pencarian nafkah, seperti telah diungkap sekilas di atas, juga mengalami pergeseran peran, jika sebelumnya yang dominan isteri maka setelah isteri tidak lagi bekerja sebagai TKW di luar negeri, maka peran pencari nafkah beralih ke tangan suami. Yang menarik kemudian adalah pengelolaan keuangan hasil pencarian nafkah itu, jika sebelumnya semua hasil kerja isteri dalam mencari nafkah itu diberikan kepada suami, maka sebaliknya ketika suami yang berperan mencari nafkah, pengelola keuangan keluarga tetap berada di tangan suami, bahkan suami hanya sekedar memberikan nafkah rutin yang dibutuhkan keluarga yang jumlah pas-pasan, dan jika terjadi kekurangan, sang harus meminta lagi kepada suami. Dan meskipun dalam kasus-kasus tertentu misalnya untuk pembelian keperluan-keperluan yang sifatnya bukan rutin tetap dimusyawarahkan antara suami dan isteri.

Kini kita beralih pada keluarga $\mathrm{S}$ dan $\mathrm{R}$. Keluarga ini tegolong unik. Setelah R tidak lagi menjadi TKW, justru keduanya bekerja serabutan sebagai buruh tani, seperti membajak sawah, menanam padi, mencabuti rumput, dan menanam padi atau palawija lainnya. Hasil dari pekerjaan itu mereka satukan untuk memenuhi kebutuhan ekonomi keluarga. Mereka sadar bahwa kebutuhan ekonomi keluarga harus mereka topang secara bersama-sama, tidak ada yang dominant dalam konteks ini. Karena itu, mereka selalu mengkomunikasikan kebutuhan ekonomi secara bersama-sama.

Berbeda dengan keluarga $\mathrm{S}$ dan $\mathrm{R}$, setelah E tidak lagi menjadi TKW di luar negeri, kendali ekonomi keluarga berada di tangan B. B kini kini membuka 
usaha Jual Jamu. Sementara E, menjadi ibu rumah tangga dengan mengerjakan seluruh pekerjaan domestik seperti terlihat di atas. Meskipun nafkah keluarga berasal dari sang suami, tapi dalam hal pengeloloaan keuangan di serahkan kepada E, sang isteri. Kecuali untuk keperluan-keperluan yang sifatnya sekunder, yakni pembelian barang-barang elektonik dan alat transportasi.

Dan memang selama E menjadi TKW di luar negeri, B tidak tinggal diam menunggu kiriman uang dari sang isteri, tetapi juga berupaya memenuhi kebutuhan ekonomi keluarga dengan cara berjualan pulsa elektronik. Baru setelah sang interi pulang keluarga ini kemudian membuka toko Jamu. Dengan kata lain, keberangkatan E ke luar negeri tidak serta merta menjadikan B menganggur, bahkan seperti terlihat dalam bab III, Sembari mencukupi kebutuhan ekonomi keluarga, B juga mengerjakan pekerjaan domestic.

\section{Pola Relasi Peran Pengasuhan Anak}

Untuk persoalan pendidikan dan perawatan anak, dalam keluarga $\mathrm{H}$ dan $\mathrm{I}$, juga mengalami pergeseran, jika sebelumnya suami dominant karena isteri bekerja di luar negeri, maka ketika isteri kembali pendidikan dan perwatan anak beralih kembali ke tangan isteri, hal itu terlihat dari pekerjaan-pekerjaan yang dilakukan sang isteri di rumah, misalna menidurkan, memandikan, menggantikan popok, menemani bermain, dan menemani belajar.

Sebaliknya dalam keluarga $\mathrm{S}$ dan $\mathrm{R}$, peran pengasuhan anak lebih dominant dilakukan oleh sang suami, salah satu penyebab mengapa hal itu bias terjadi karena tenggang waktu $\mathrm{R}$ yang lama berada di luar negeri membuat sang anak lebih dekat kepada Bapaknya. Karena itu, sang bapak biasa untuk menidurkan, mamandikan, menggantikan, menyuapi, dan menemani belajar. Kondisi ini, justru menguntungkan bagi sang isteri, R, sebab dengan kondisi itu, $\mathrm{R}$ dapat bekerja sebagai buruh tani, tanpa harus terbebani oleh pekerjaan mengasuh anak.

Keluarga B dan E berbeda lagi. Dalam keluarga ini, pengasuhan anak mereka lakukan secara bersama-sama sejak menidurkan, memandikan, menyuapi, mengantar sekolah, menjemput sekolah, dan menemani belajar. Prinsip pengasuhan anak bagi mereka adalah siapa yang sempat dialah yang menjalani 
tugas itu, jadi tidak ada pemaksanaan tugas yang harus diperankan oleh satu anggota keluarga.

\section{Interpretasi Pola Pergeseran Peran}

Secara umum dapat dikatakan bahwa keluarga pola relasi suami-isteri keluarga mantan TKW yang menjadi focus penelitian tidak mengalami pergeseran peran yang berarti. Keluarga $\mathrm{H}$ dan I misalnya sebelum sang isteri berangkat menjadi TKW keluarga tentu membagi peran sebagaimana layaknya sebuah keluarga yang dibangun berdasarkan budaya patriarkhi. Baru setelah sang isteri pergi bekerja ke luar negeri, ada perubahan peran yang dimainkan, sang isteri beralih menjadi tumpuan dalam mencari dan memenuhi ekonomi keluarga, maka ketika suami mengambil alih peran isteri sebagai penanggungjawab kerja domestik dan pendidikan anak. Selama enam tahun kondisi seperti berjalan, tapi tidak memiliki pengaruh yang kuat terhadap pembentukan kesadaran bahwa keluarga mestilah dibangun atas kesetaraan dan keadilan peran, dalam pengertian bahwa kerja domestik dan perawatan atau pendidikan anak sejatinya bukan sesuatu yang diberikan secara kodrati sebagai pekerjaan isteri, suami mestinya bisa bertukar peran secara adil dengan sang isteri meskipun ia menjadi penanggungjawab nafkah keluarga.

Berdasarkan riwayat hidup keluarga $\mathrm{H}$ dan $\mathrm{I}$ diketahui sang suami sejatinya memiliki pengetahuan keagamaan yang cukup mumpuni, dia bergelar alHafidh, yakni orang yang hafal al-Qur'an, di sisi lain, ia juga adalah seorang guru ngaji di kampongnya. Dari sisi ini, mestinya dia mampu mencerap ajaran Islam yang egaliter dan tidak mengamalkan pemahaman keagamaan yang bias gender. Tapi itu justru tidak terjadi. Karena itu, dapat dikatakan bahwa kuat pengaruh nilai-nilai budaya yang bias gender dan telah lama membekas dalam kesadaran sang suami mengantarkan keluarga itu tidak mampu menciptkan relasi yang setara dan adil dalam perspektif gender.

Selanjutnya dalam keluarga S dan R, dapat dilihat hal yang berbeda, baik sang suami maupun sang isteri alumni pondok pesantren, selama 5 tahun mereka menuntut ilmu agama di lembaga itu. Tentu saja dapat diandaikan mereka punya basis pemahaman keagamaan yang lumayan. Sang isteri Rohmi 4 kali menjadi 
TKW masing-masing 2 tahun, jadi bisa dikatakan bahwa Rohmi menjadi TKW selama 8 tahun. Tapi yang menarik sejak membina keluarga keduanya sudah saling membantu dalam melaksanakan tugas-tugas mereka. Tidak ada yang dominant dalam pembagian tugas-tugas itu. Baik sebelum maupun sesudah sang isteri menjadi TKW tugas-tugas public seperti mencari nafkah mereka lakukan berdua, begitu juga halnya dengan peran-peran privat selalu mereka lakukan bersama. Pertanyaan yang bias diajukan kemudian mengapa kesetaraan dan keadilan peran gender dalam keluarga ini bias terjadi?

Tentu kita tidak bisa mengandaikan bahwa pemahaman keagamaan mereka tidak bias gender, tapi sebab data yang digali tidak sampai menyentuh ke persoalan itu, yang bias diraba kemudian adalah kesadaran pembagian peran yang adil barangkali berdasar akan kondisi keluarga yang alami. Secara ekonomi keluarga terbilang pas-pasan, baik sang suami dan sang isteri sama-sama bekerja sebagai buruh tani. Dari kondisi itu barangkali terbangun sebuah kebersamaan yang alamiah: tidak ada marginalisasi, tidak sub-ordinasi, tidak stereotype, dan tidak beban ganda, semua mereka kerjakan secara bersama-sama.

Yang terakhir adalah keluarga B dan E. Mereka hidup dalam lingkungan masyarakat yang agamis. Sehari-hari sang suami bekerja sebagai pedagang: couter hand phone dan toko Jamu. Berbeda dengan dua keluarga sebelumnya baik sang isteri maupun sang suami sama pernah menjadi TKI di luar negeri: B pernah bekerja selama 2 tahun di Malaisia sementara E pernah bekerja 2 tahun di Arab Saudi. Tapi yang menarik meskipun keduanya pernah berperan sebagai penanggungjawab ekonomi keluarga relasi peran yang mereka bangun tidak banyak mengalami pergerseran. Kini B berperan sebagai penanggungjawab ekonomi keluarga, dan E bertanggungjawab sebagai pekerja domestik. Hamper semua pekerjaan domestic dikerjakan oleh sang isteri, karena menurut sang suami begitulah seharus kerja isteri. Peran isteri menjadi begitu dominant dalam pekerjaan domestik. Kecuali dalam hal pengasuhan dan pendidikan anak mereka lakukan secara bersama-sama. Kesetaraan peran dan keadilan gender tidak berlaku dalam keluarga ini. Kuatnya budaya patriarkhi yang mendominasi dalam benak sang suami menciptakan kondisi yang tidak peka gender dalam keluarga. Sebab begitulah seharusnya sebuah keluarga, kata sang suami. Laki-laki berperan 
sebagai kepala rumah tangga yang berhak mengatur rumah tangga sementara sang isteri harus menjalani kodratnya sebagai isteri yang cukup puas dengan kerja-kerja domestik, meskipun sang isteri punya pengalaman dan kontribusi ekonomi kepada keluarga terutama ketika sang isteri manjadi TKW selama 2 tahun di Arab Saudi.

\section{E. Kesimpulan}

Pergeseran pola relasi peran suami-isteri dalam tiga keluarga mantan TKW sejatinya terjadi tapi tidak bersifat permanent dalam arti bahwa pergeseran peran hanya terjadi terutama pada saat sang isteri dari keluarga H-I dan keluarga B-E bekerja di luar negeri. Setelah sang isteri dari kedua keluarga itu kembali ke tengah-tengah keluarga pola relasi peran berjalan sebagaimana yang dulu pernah mereka bangun: sang suami kembali dominan dalam pemenuhan ekonomi keluarga sementara sang isteri juga kembali menekuni pekerjaan domestic dan pengasuhan anak. Meskipun dalam keluarga B-E, juga terlibat dalam pengasuhan anak. Sementara dalam keluarga S-R, tidak tidak terjadi perubahan pola relasi peran, sebab sejak semula dalam keluarga ini baik suami maupun isteri saling membantu dalam menjalankan peran penanggungjawab ekonomi, kerja domestic dan pengasuhan anak. Artinya baik sebelum maupun sesudah menjadi TKW keduanya telah terbiasa membagi tugas secara setara dan seimbang.Terjadinya pergeseran pola relasi peran yang terjadi dalam keluarga H-I dan B-E dipicu oleh fakor kondisi masing-masing keluarga. Kondisi itu adalah ketiadaan sang isteri di dalam rumah tangga karena sedang bekerja di luar negeri.

Terdapat perbedaan pergeseran pola relasi dalam tiga keluarga mantan TKW. Perbedaan itu, terlihat mencolok terutama pada keluarga H-I dan S-R, kedua keluarga ini sang suami memiliki pengetahuan keagamaan yang cukup berdasarkan latar belakang pendidikan mereka. Sang suami dalam kedua keluarga ini, sama-sama lulusan pesantren, tetapi dalam hal relasi peran yang dibangun dalam keluarga mereka berbeda. Dalam keluarga H-I, sang suami memandang tugas isteri merupakan kodrat yang semestinya diemban oleh sang isteri, sementara dalam keluarga S-R, sang suami berpendapat sebaliknya, yakni relasi peran dalam keluarga bukanlah sesuatu yang kodrati, melainkan peran yang dibangun berdasarkan kontruksi social yang ada di tengah-tengah masyarakat. 
Meskipun harus dikatakan bahwa dalam keluarga S-R, kesadaran kesetaraan peran antara suami dan isteri lebih disebabkan oleh kesadaran kondisi keluarga yang hidup dalam kondisi serba pas-pasan, dan bukan terbangun oleh kesadaran yang berbasis pada pemahaman keagamaan.

\section{BIBLIOGRAFI}

Daulay, Harmona. Pergeseran Pola Relasi Gender di Kelurga Migran Studi

Kasus TKIW di Kecamatan Rawamrta Kabupaten Karawang Jawa Barat, Yogyakarta: Galang Press, 2001.

Haris, Abdul. Memburu Ringgit Membagi Kemiskinan: Fakta di Balik Migrasi Orang Sasak ke Malaysia, Yogyakarta: Pustaka Pelajar, 2002

Kantor Menteri Negara Pemberdayaan Perempuan RI, 2002, Buku 2, Bahan Informasi Pengarusutamaan Gender, Edisi ke-2, Bagaimana Mengatasi Kesenjangan Gender.

Kantor Menteri Negara Pemberdayaan Perempuan RI, 2002, Buku 1, Bahan Informasi Pengarusutamaan Gender, Edisi ke-2, Apa Itu Gender.

Madjid, Nurcholish, Masyarakat Religius, Jakarta: Paramadina, 1997

Ma'ruf, Farid, “Kleuarga Sakinah, Keluarga Dambaan”, Makalah tidak diterbitkan

Muhammad, Husein, Fikih Perempuan: refleksi Kiai atas Wacana Agama dan Gender Yogyakarta: Lkis, 2001.

Mulia, Siti Musda, "Keluarga Sakinah sebagai Benteng Budaya Korupsi" Makalah Seminar tidak diterbitkan

Profil Gender Kabupaten Ponorogo Tahun 2005, Ponorogo: Pemkab PonorogoPSW STAIN Ponorogo, 2006

Rokamah, Ridho. "Mekanisme Pengiriman dan Perlindungan Hukum TKW ke Luar Negeri di Kabupaten Ponorogo" dalam Kodifikasia, No. 1 Tahun 2007.

Suchamdi, Pengaruh Income TKW Terhadap Tingkat Kesejahteraan Keluarga di Desa Polorejo Kecamatan Babadan Kabupaten Ponorogo: Telaah atas Hak dan Kewajiban Suami Isteri Menurut Fiqh Islam, Yogyakarta: Tesis Magister Studi Islam UII, 2003.

Suratiyah, Ken dan Sunarru Samsi Hariadi dalam Wanita, Kerja, dan Rumah Tangga Pengaruh pembangunan Pertanian terhadap Peran Wanita 
Pedesaan di Daerah Istimewa Yogyakarta (Yogyakarta: Pusat Penelitian UGM, 1991), h. 8-9.

Syamsiatun, Siti. "Relasi Gender Antar Anggota Keluarga: Pengalaman Tiga Perempuan dalam Perspektif Agama dan perubahan Sosial" dalam Musawa, Vol. 3, No. 2 September 2004, h. 187-208.

Wahyuni Dj, Ekapi "Pergeseran Peran dan Fungsi Suami terhadap Pendidikan Anak dalam Keluarga Tenaga Kerja Wanita di Luar Negeri," dalam Fenomena Vol. 4 No. 2, Juli 2007. 